\title{
A new method for the stereoselective synthesis of macrodiolides from TADDOL derivatives
}

\author{
Andrea R. Costantino ${ }^{a b} *$, Sandra D. Mandolesi ${ }^{a}$, Liliana C. Koll ${ }^{\text {ab }}$ \\ a Instituto de Química del Sur (INQUISUR), Departamento de Química, Universidad Nacional del Sur, \\ Avenida Alem 1253, 8000 Bahía Blanca, Argentina \\ ${ }^{b}$ CONICET, Argentina. E-mail: andrea.costantino@uns.edu.ar; Ickoll@criba.edu.ar ; \\ sdmando@criba.edu.ar
}

* Author to whom correspondence should be addressed.

\begin{abstract}
In previous studies, we reported the stereoselective radical addition of organotin hydrides to unsaturated TADDOL diesters. These reactions occurred with intramolecular cyclization under inert atmosphere, radical initiator, toluene and $75^{\circ} \mathrm{C}$ with high yields and stereoselectivity depending on the reactivity and steric bulk of the organotin hydride employed. ${ }^{1}$ Here, we decided to study a new method for the synthesis of these macrocycles through the radical addition of different triorganotin hydrides, $\mathrm{R}_{3} \mathrm{SnH}$ ( $\mathrm{R}=\mathrm{Me}, n-\mathrm{Bu}, \mathrm{Ph}$; Neophyl), to the same unsaturated TADDOL diesters, in THF as solvent and under MW conditions. We compared these results with the previous reported method. ${ }^{1}$ Under MW conditions, reactions were completed in very short time and neither the double hydrostannation nor the cyclopolymerization products were obtained in both cases. Furthermore, we evaluated the stereoselectivity by ${ }^{119} \mathrm{Sn}-\mathrm{NMR}$ spectroscopic analysis in both methods.
\end{abstract}

Keywords. Cyclohydrostannation, Macrodiolides, TADDOL unsaturated diesters

\section{Introduction}

Natural products containing macrolides, i.e., macrolactones with rings that contain eight or more members, are found in plants, insects, and bacteria. Because of their biological and medicinal activity, macrolides are very important target molecules in synthetic studies. Though many of the antibiotic macrolides have highly substituted complex structures, also the simple ones have properties that make them worth studying. ${ }^{2}$ Macrocyclic structures with more than one ester linkage are also classified as macrolides. ${ }^{3}$ A number of synthetic strategies and methodologies have been developed for macrolide synthesis. However, the construction of the macrocyclic structures is a frequent and challenging problem in synthetic organic chemistry due to the fact that most of these syntheses involve many steps, and the global yields are very low. ${ }^{3}$ In the area of free radical macrocyclizations, the studies of Porter enabled defining conditions wherein intramolecular addition of carbon radicals to electron-deficient alkenes provides an effective tool for the synthesis of 11-20-membered carbocycles. ${ }^{4}$ We have recently reported a new approach based upon the fact that free radical addition of triorganotin hydrides to unsaturated diesters of TADDOL leads via a tandem cyclohydrostannation to mixtures of 11-membered organotin-substituted macrodiolides in high yields and with good diastereoselectivity, and no polymerization or diaddition products observed (Scheme 1). 


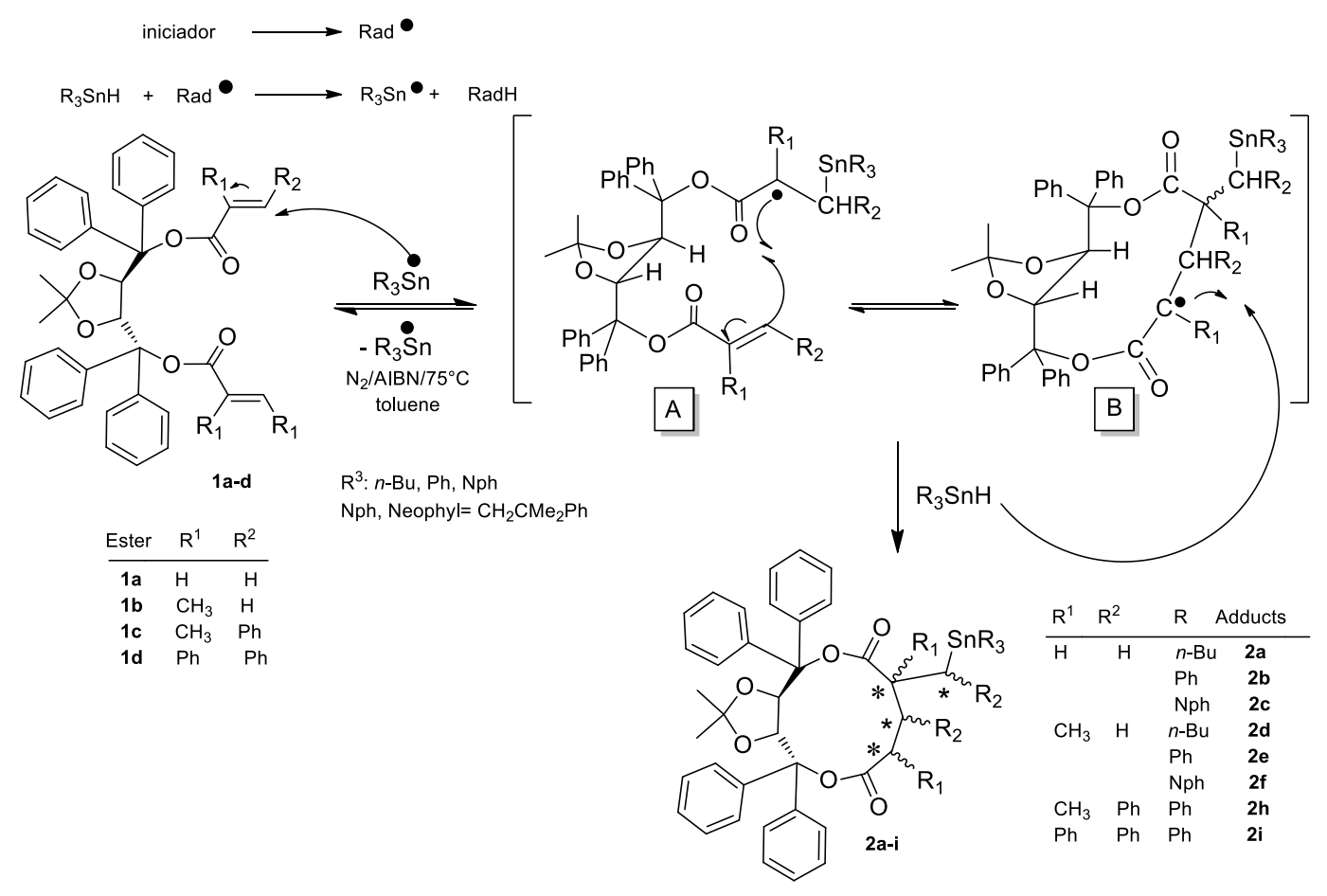

Scheme 1

It was also found that whereas the addition of these hydrides to TADDOL diacrylate and TADDOL dimethacrylate leads to the expected mixtures of two and four cycloundecane diastereoisomers, respectively, the addition of triphenyltin hydride to TADDOL disubstituted acrylates yields only four out of the 16 possible stereoisomers. The observed stereoselectivity is consistent with the radical tandem cyclohydrostannation mechanism proposed.

Then, we development the cyclohydrostannation reactions with diorganotin halohydride. ${ }^{5}$ The use of diorganotin chlorohydrides leads to much more stereoselective cyclohydrostannations than those carried out using triorganotin hydrides. However, they are reactive extremely unstable and requires an extra step of synthesis.

Single-enantiomer drug candidates are important to many pharmaceutical companies, and therefore, new methods for the preparation of enantiopure compounds are critical for the development of next-generation pharmaceutical products. ${ }^{6}$ The use of microwave (MW) irradiation in organic synthesis has become a popular technique to develop and optimize the synthesis of libraries of compounds in short reaction time compare to those obtained with the classical thermal methods in pharmaceutical and academic production. ${ }^{7}$ Numerous studies in the past ten years, demonstrated that microwave enhanced chemical reactions and that they are faster than conventional heating methods. So, we decided to study a new procedure for the synthesis of these macrocycles through the radical addition of different triorganotin hydrides, $\mathrm{R}_{3} \mathrm{SnH}(\mathrm{R}=\mathrm{Me}, n-\mathrm{Bu}, \mathrm{Ph}$; Neophyl), to the same unsaturated TADDOL diesters, in THF as solvent ${ }^{8}$ and under MW conditions. Based on previous reports, ${ }^{1}$ We changed the solvent toluene by THF. Furthermore, the Dielectric Constant $\left(\varepsilon^{\prime}\right)$ and Tan $(\delta)$ of THF is greater than toluene, due to the better ability of THF to absorb microwave energy. 


\section{Results and Discussions}

The addition under free radical conditions of triorganotin hydrides to TADDOL diacrylate in THF, using ratios tin hydride $/ \mathbf{1} \mathbf{a}-\mathbf{d}=1.5$ (tin hydride concentration $=0.085 \mathrm{M}$ ) under thermal and microwaves conditions, leads in both cases to products of cyclohydrostannation as shown in Table 1. It should be noted that neither double hydrostannation nor cyclopolymerization products were obtained.

The ${ }^{119}$ Sn NMR spectroscopic analysis of the crude products from the additions of tri- $n$-butyl, triphenyl and trineophyltin hydrides to ester 1a showed the expected two signals corresponding to the ${ }^{119} \mathrm{Sn}$ present in each one of the diasteroisomers. Besides, it also shows that they were formed in different proportions, indicating some diasteroselectivity. As shown in Table 1, the diasteroisomeric relations (D\%) were high with $\mathrm{Ph}_{3} \mathrm{SnH}$ for both conditions. With other hydrides also a slight increase or a similar result is observed. The diastereoisomer obtained in higher proportion is that corresponding to a signal at $-11.96 \mathrm{ppm}$. Regarding the reaction times the condition $B$ is the best ( $5 \mathrm{~min}$ ).

Under the same free radical conditions, the reaction between TADDOL dimetacrylate $\mathbf{1} \mathbf{b}$ and the triorganotin hydrides, showed only cyclohydrostannation products. The ${ }^{119} \mathrm{Sn} \mathrm{NMR}$ spectroscopic analysis of the crude reactions showed three or four diasteroisomers, in different proportion, that are consistent with the formation of two new stereogenic centers. Reaction condition B was the best method for this substrate with $\mathrm{Bu}_{3} \mathrm{SnH}$ and $\mathrm{Ph}_{3} \mathrm{SnH}$. Respect $\mathrm{Nph}_{3} \mathrm{SnH}$ only two diasteroisomers were observed under reaction condition A (Entry 11).

Similar studies on the hydrostannation of TADDOL di(2-methyl-3-phenyl) 1 c and di(2.3diphenyl)acrylates $\mathbf{1 d}$ showed that the free radical addition of triphenyltin hydride leads to the same products of ciclohydrostannation reported previously. ${ }^{1}$ Substrate $1 \mathrm{c}$ showed similar results with the two methods tested but the diasteroselectivities obtained are lower (Method $A, D \%=10,14,18,58$; and Method $B, D \%=16,16,14,56)$ than the previous report $(D \%=6,10,13,71)$. The best condition was $A$ where the diastereoselectivity obtained is greater than reported $(D \%=25,3,10,62)$.

Table 1.

\begin{tabular}{|c|c|c|c|c|c|c|c|c|c|}
\hline Entry & $\mathrm{R}^{1}$ & $\mathbf{R}^{2}$ & Ester & $\mathbf{R}$ & Condition $^{a}$ & ${ }^{119}$ Sn NMR ${ }^{b}$ & D \% ${ }^{\mathrm{c}}$ & $\begin{array}{l}\text { Time } \\
\text { (min) }\end{array}$ & D $\%^{d}$ \\
\hline 1 & \multirow[t]{3}{*}{$\mathrm{H}$} & \multirow[t]{3}{*}{$\mathrm{H}$} & \multirow[t]{10}{*}{$1 a$} & \multirow[t]{3}{*}{$n-\mathrm{Bu}$} & A & \multirow{3}{*}{$\begin{array}{r}-11.96 \\
-8.02\end{array}$} & 89 & 60 & \multirow{3}{*}{$\begin{array}{l}90 \\
10\end{array}$} \\
\hline & & & & & & & 11 & & \\
\hline 2 & & & & & B & & $\begin{array}{r}93 \\
7\end{array}$ & 5 & \\
\hline 3 & \multirow[t]{4}{*}{$\mathrm{H}$} & \multirow[t]{4}{*}{$\mathrm{H}$} & & \multirow[t]{4}{*}{$\mathrm{Ph}$} & A & \multirow{4}{*}{$\begin{array}{r}-103.91 \\
-99.92\end{array}$} & 94 & 90 & \multirow{4}{*}{$\begin{array}{l}62.5 \\
37.5\end{array}$} \\
\hline & & & & & & & 6 & & \\
\hline 4 & & & & & B & & 81 & 5 & \\
\hline & & & & & & & 19 & & \\
\hline 5 & \multirow[t]{3}{*}{$\mathrm{H}$} & \multirow[t]{3}{*}{$\mathrm{H}$} & & \multirow[t]{3}{*}{ Nph } & A & \multirow{3}{*}{$\begin{array}{l}-41.38 \\
-39.54\end{array}$} & $>99$ & 60 & \multirow{3}{*}{$\begin{array}{r}99.5 \\
0.5\end{array}$} \\
\hline & & & & & & & & & \\
\hline 6 & & & & & B & & $>99$ & 5 & \\
\hline 7 & \multirow[t]{8}{*}{$\mathrm{H}$} & \multirow[t]{8}{*}{$\mathrm{Me}$} & \multirow[t]{8}{*}{$1 b$} & \multirow[t]{8}{*}{$n-\mathrm{Bu}$} & $A$ & \multirow{8}{*}{$\begin{array}{l}-14.59 \\
-19.33 \\
-19.82 \\
-24.46\end{array}$} & 28 & 90 & \multirow{8}{*}{$\begin{array}{l}20 \\
10 \\
55 \\
15\end{array}$} \\
\hline & & & & & & & 39 & & \\
\hline & & & & & & & 21 & & \\
\hline & & & & & & & 12 & & \\
\hline 8 & & & & & B & & 21 & 5 & \\
\hline & & & & & & & 50 & & \\
\hline & & & & & & & 14 & & \\
\hline & & & & & & & 15 & & \\
\hline
\end{tabular}




\begin{tabular}{|c|c|c|c|c|c|c|c|c|c|}
\hline 9 & \multirow[t]{7}{*}{$\mathrm{H}$} & \multirow[t]{7}{*}{$\mathrm{Me}$} & & \multirow[t]{7}{*}{$\mathrm{Ph}$} & A & \multirow{7}{*}{$\begin{array}{l}-109.04 \\
-112.82 \\
-114.94 \\
-116.41\end{array}$} & 24 & 120 & \multirow{7}{*}{$\begin{array}{r}17 \\
56 \\
22 \\
5\end{array}$} \\
\hline & & & & & & & 1 & & \\
\hline & & & & & & & 36 & & \\
\hline & & & & & & & 39 & & \\
\hline 10 & & & & & \multirow[t]{3}{*}{ B } & & 21 & 25 & \\
\hline & & & & & & & $\begin{array}{r}\text { n. o. } \\
24\end{array}$ & & \\
\hline & & & & & & & 55 & & \\
\hline \multirow[t]{4}{*}{11} & \multirow[t]{8}{*}{$\mathrm{H}$} & \multirow[t]{8}{*}{ Me } & & \multirow[t]{8}{*}{ Nph } & A & \multirow{8}{*}{$\begin{array}{l}-43.79 \\
-45.25 \\
-48.92 \\
-51.85\end{array}$} & n.o. & 60 & \multirow{8}{*}{$\begin{array}{r}47 \\
6 \\
5 \\
42\end{array}$} \\
\hline & & & & & & & n.o. & & \\
\hline & & & & & & & 53 & & \\
\hline & & & & & & & 47 & & \\
\hline \multirow[t]{4}{*}{12} & & & & & B & & 40 & 25 & \\
\hline & & & & & & & 6 & & \\
\hline & & & & & & & 6 & & \\
\hline & & & & & & & 47 & & \\
\hline \multirow[t]{4}{*}{13} & \multirow[t]{8}{*}{$\mathrm{Me}$} & \multirow[t]{8}{*}{$\mathrm{Ph}$} & \multirow[t]{8}{*}{ 1c } & \multirow[t]{8}{*}{$\mathrm{Ph}$} & A & \multirow{8}{*}{$\begin{array}{l}-119.12 \\
-127.18 \\
-135.84 \\
-141.40\end{array}$} & 10 & 360 & \multirow{8}{*}{$\begin{array}{r}6 \\
10 \\
13 \\
71\end{array}$} \\
\hline & & & & & & & 14 & & \\
\hline & & & & & & & 18 & & \\
\hline & & & & & & & 58 & & \\
\hline \multirow[t]{4}{*}{14} & & & & & B & & 16 & 60 & \\
\hline & & & & & & & 16 & & \\
\hline & & & & & & & 14 & & \\
\hline & & & & & & & 56 & & \\
\hline \multirow[t]{4}{*}{15} & \multirow[t]{8}{*}{$\mathrm{Ph}$} & \multirow[t]{8}{*}{$\mathrm{Ph}$} & \multirow[t]{8}{*}{$1 d$} & \multirow[t]{8}{*}{$\mathrm{Ph}$} & A & \multirow{8}{*}{$\begin{array}{l}-121.66 \\
-127.07 \\
-135.76 \\
-141.29\end{array}$} & 1 & 360 & \multirow{8}{*}{$\begin{array}{r}25 \\
3 \\
10 \\
62\end{array}$} \\
\hline & & & & & & & 3 & & \\
\hline & & & & & & & 1 & & \\
\hline & & & & & & & 95 & & \\
\hline \multirow[t]{4}{*}{16} & & & & & $B$ & & 24 & 60 & \\
\hline & & & & & & & 5 & & \\
\hline & & & & & & & $\begin{array}{r}4 \\
67\end{array}$ & & \\
\hline & & & & & & & 67 & & \\
\hline
\end{tabular}

${ }^{a}$ Condition A: thermal condition $\left(70^{\circ} \mathrm{C}\right.$, THF as solvent); B: $\mathrm{MW}\left(75^{\circ} \mathrm{C}, 200 \mathrm{~W}\right.$, THF as solvent). ${ }^{\mathrm{b}}$ In $\mathrm{CDCl}_{3}$ in ppm with respect to $\mathrm{Me}_{4} \mathrm{Sn} .{ }^{\mathrm{C}} \mathrm{D}=\%$ of diasteroisomer in the mixture (from ${ }^{119} \mathrm{Sn}$ NMR spectra) ; ${ }^{\mathrm{d}} \mathrm{D} \%$ according to result of reference 1.

The structures and ${ }^{119} \mathrm{Sn}-\mathrm{NMR}$ spectra of the predominant adducts are shown in Scheme 2.

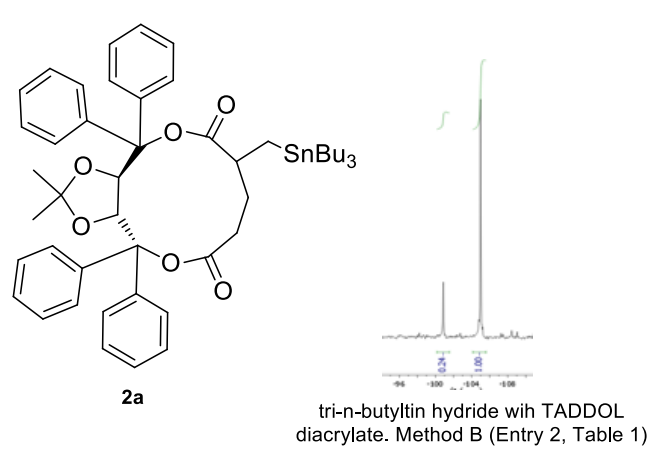<smiles>CC1(C)O[C@@H]2C(c3ccccc3)C(c3ccccc3)(c3ccccc3)OC(=O)CCC(C[SbH2])C(=O)OC(c3ccccc3)(c3ccccc3)[C@@H]2O1</smiles>

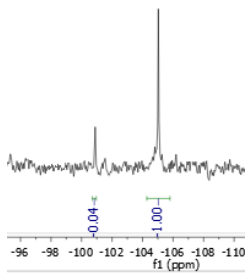

triphenyltin hydride wih TADDOL diacrylate. Method A (Entry 3, Table 1) 

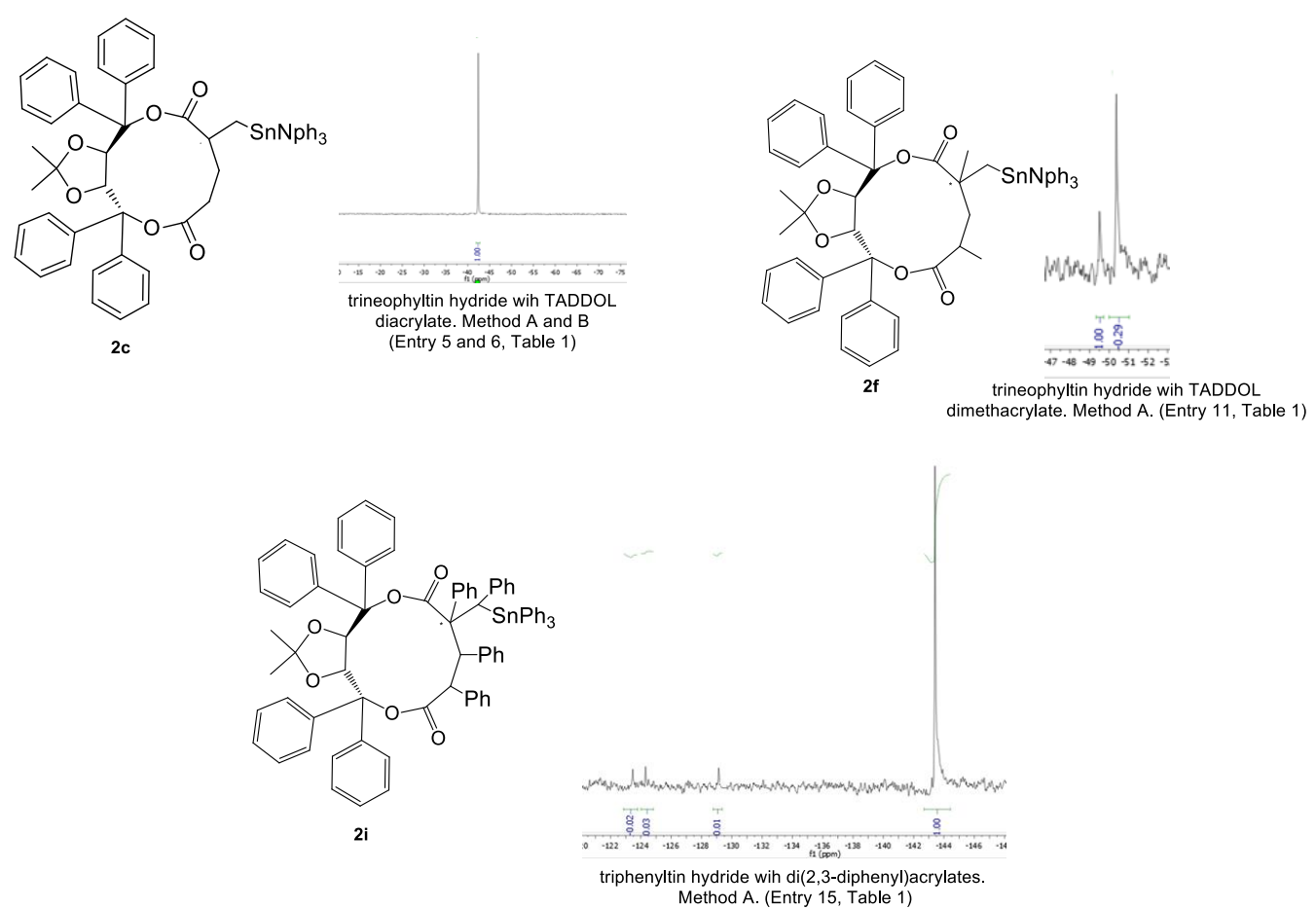

Scheme 2

\section{Conclusions}

In these studies, it can be observed that, in the current reaction conditions proposed here, five of eight adducts (2a, 2b, 2c, 2f, 2i) were synthetized with better diasteroselectivity than those reported previously. High diasteroselectivity was obtained for adduct $\mathbf{2 c}$ both for methods A and B.

Future studies with halotrialkyltin or haloalkyldiaryltin compounds will be achieved.

\section{Experimental Section}

\section{General methods}

Unless otherwise noted, all reagents were purchased from commercial suppliers and used without purification. $\mathrm{Bu}_{3} \mathrm{SnH}$ (CAS Number 688-73-3) and $\mathrm{Ph}_{3} \mathrm{SnH}$ (CAS Number 892-20-6) are commercially available or can be synthesized as indicated in the references. ${ }^{9}$ Synthesis of $\mathrm{Neof}_{3} \mathrm{SnH}^{9}$ was made following the reference method. THF was dried by refluxing and distilling in inert atmosphere with sodium and benzophenone as indicator. Thin layer chromatography was performed on Merck precoated silica gel 60 F254 plates and visualization was accomplished with UV light and/or 5\% ethanol solution of phosphomolibdic acid. Silica gel (Merck, 230-400 mesh) was used for column chromatography. Infrared spectra were recorded with a Nicolet Nexus 470 FT spectrometer. NMR spectra were recorded on a Bruker ARX 300 Multinuclear instrument, using $\mathrm{CDCl}_{3}$ as solvent. Compounds described in the literature were characterized by comparison of their ${ }^{1} \mathrm{H}-,{ }^{13} \mathrm{C}$ - and ${ }^{119} \mathrm{Sn}$ NMR and IR spectra to the previously reported data. . Microwave reactions were carried out in a microwave CEM Discover ${ }^{\circledR}$ at $200 \mathrm{~W}, 75^{\circ} \mathrm{C}$. 


\section{Method A.}

Diester $(1 \mathrm{mmol})$ in dry THF $(17 \mathrm{~mL})$ was treated with triorganotin hydrides $(1.5 \mathrm{mmol})$, using AIBN as radical initiator $(0.15 \mathrm{mmol})$, in nitrogen atmosphere, at $70^{\circ} \mathrm{C}$ during the time indicated in Table 1. Optimal reaction time and adequate excess of organotin hydride were determined by monitoring the reaction through IR analysis (observing the disappearance of $\mathrm{Sn}-\mathrm{H}$ absorption). The resultant solution was concentrated under reduced pressure. The crude product was analyzed by ${ }^{119} \mathrm{Sn} \mathrm{NMR}$.

\section{Method B.}

Diester $(1 \mathrm{mmol})$ in dry THF $(17 \mathrm{~mL})$ was mixed with triorganotin hydrides $(1.5 \mathrm{mmol})$ and AIBN as radical initiator $(0.15 \mathrm{mmol})$. The tube was purged by 3 cycles of vacuum-nitrogen and then taken quickly to the microwave device. The mixture was irradiated at $200 \mathrm{~W}$ during the times reported in Table 1 . The microwave was programmed to give a maximum internal temperature to $70^{\circ} \mathrm{C}$.

\section{Acknowledgments}

This work was supported by grants from ANPCyT (Capital Federal, Argentina), CONICET (Buenos Aires, Argentina) and Universidad Nacional del Sur (Bahía Blanca, Argentina). A fellowship from CONICET to ARC is acknowledged.

\section{References}

${ }^{1}$ Gerbino, D. C.; Koll, L. C.; Mandolesi, S. D.; Podestá, J. C. Organometallics 2008, 27, 660-665.

${ }^{2}$ Gerbino,D. C.; Scoccia, J.; Koll, L. C; Mandolesi, S. D.; Podesta, J. C. Organometallics 2012, 31, 662-671.

${ }^{3}$ Nicolaou, K. C. Tetrahedron, 1977, 33, 683-710.

${ }^{4}$ (a) Porter, N. A.; Chang, V. H.-T. J. Am. Chem. Soc. 1987, 109, 4976-4981. (b) Porter, N. A.; Lacher, B.; Chang, V. H.; Magnin, D. R. J. Am. Chem. Soc. 1989, 111, 8309-8310.

${ }^{5}$ Gerbino,D. C.; Scoccia, J.; Koll, L. C; Mandolesi, S. D.; Podesta, J. C. Organometallics 2012, 31, 662-671.

${ }^{6}$ Kavanagh, Y.; Ford, L.; Schiesser, C. H. Organometallics 2011, 30, 4387-4392.

7 a) Hayes, B. L. Microwave Synthesis. 2002. b) Lidstrom, P.; Tierney, J.; Wathey, B.; Westman, J. Tetrahedron, 2001, 57, 9225-9283.

${ }^{8}$ Nakamura, E.; Imanishi, Y.; Machii, D. J. Org. Chem. 1994, 59, 8178-8186.

${ }^{9}$ Buschhaus, H. U.; Lehnig, M.; Neumann, W. P. J. Chem. Soc., Chem. Commun., 1977, 129. 